\title{
PENDIDIKAN MULTIKULTURAL DALAM BUDAYA NEMUI NYIMAH
}

\section{Muhammad Candra Syahputra*}

\begin{abstract}
Abstact: Indonesia is a country that consist of various tribes, cultures, customs, religions and beliefs. This has become a special asset for the Indonesian people, but on the other hand it has also been disastrous because it can cause conflict with the another. Therefore the need to instill multicultural in people's lives, certainly through education. Multicultural education should be taken from existing local wisdom, in here the author will take the local wisdom of Lampung which is called nemui nyimah as the basis of multicultural education in Lampung. This research uses a qualitative approach, with the literature study method, with indepth analysis based on available data sources. The resukts of this study that the culture of nemui nyimah contained multicultural values such as sharing with guests, being friendly to guests, good manners, being generous with guests, which later could be developed in a formal education environtment.
\end{abstract}

Key Words: Multicultural Education, Local Wisdom, Pluralism

\section{Pendahuluan}

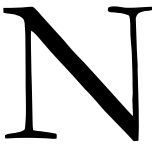

egara Kesatuan Republik Indonesia (NKRI) merupakan negara dengan penduduk yang beragam atau disebut masyarakat yang majemuk, dapat kita lihat dari segi geografis maupun kondisi sosio-kultural yang amat sangat beragam yang terbentang dari Sabang sampai Merauke terdiri dari bermacam suku, budaya, agama, adat istiadat.

${ }^{*}$ Mahasiswa Pascasarjana UIN Sunan Ampel Surabaya email: candrasyach@gmail.com 
Bagaimana tidak, negeri ini memiliki pulau dengan jumlah 13.000 dan terdapat lebih dari 300 suku bangsa, dan menggunakan 200 bahasa yang berbeda-beda (Yaqin, 2005: 4). Kemajemukan merupakan suatu kenyataan yang tidak dapat dihindari atau ditolak (Naim 2016: 204). Keberagamaan telah menjadi bagian atau satu kesatuan yang tidak dapat dipisahkan dalam kehidupan sehari-hari. Kemajemukan sebagai bagian yang erat kaitannya dengan kehidupan harus dipahami, diterima, dan diapresiasi secara konstruktif. Sikap demikian akan dapat memberikan kontribusi bagi terwujudnya kerukunan.

Menurut Masdar Hilmy sekalipun pluralisme dan multikulturalisme merupakan fakta keras (hard fact) dan "hukum Islam" (sunatullah) yang harus pasti ada, banyak orang yang tidak mengakui kenyataan pluralisme dan multikulturalisme tersebut. Akibatnya, manusia sering terjebak pada truth claim yang bisa mengarah pada perpecahan dan konflik manifest (Hamdi, 2017: 31-32). Secara normatif, agama-agama juga sebenarnya sudah mengajarkan bahwa manusia terlahir membawa karakter, sifat, dan identitas primodial yang beragam. Islam misalnya mengajarkan bahwa umat manusia diciptakan berbangsa-bangsa dan bersukusuku, hal demikian tidak lain hanya agar mereka saling mengenal.

Realitas keanekaragaman yang dimiliki bangsa Indonesia dapat berubah menjadi malapetaka jika perbedaan itu tidak dipahami sebagai suatu keniscayaan (Naim, 2015: 73). Keanekaragaman disatu sisi adalah suatu khazanah bangsa, namun disatu sisi dapat menimbulkan konflik baik antar suku maupun antar agama. Di Indonesia, seringkali kita temui kerusuhan atau konflik yang muncul akibat perbedaan agama dan suku, ketika penulis mencoba mencari di internet melalui mesin pencari google dengan kata kunci "konflik" maka akan banyak sekali berita atau informasi yang muncul mengenai konflik yang disebabkan oleh perbedaan agama maupun suku.

Dalam ajaran agama juga diperintahkan untuk hidup saling rukun satu-sama lain ditengah perbedaan, bukan malah sebaliknya. Tiap-tiap agama, memiliki ajaran yang bersifat kepercayaan atau 
keimanan dan ibadat. Tidaklah cukup apabila hanya memiliki keyakinan (iman) terhadap Tuhan, melainkan perlunya dimanifestasikan dalam serangkaian peribadatan.

Dalam ajaran Islam, orang yang percaya kepada Allah, maka dirinya harus melaksanakan perintah-Nya dan menjauhi laranganNya. Aturan yang berkenaan dengan perintah dan larangan inilah yang menjadi dasar hubungan manusia dengan Allah, disebut ibadah, yaitu suatu usaha seseorang dalam rangka mendekatkan dirinya pada Allah.

Ibadah ini ada dua macam yaitu: pertama, ibadah yang sifatnya individual, yaitu ibadah yang manfaatnya pada peribadinya sendiri. Kedua, ibadah yang sifatnya sosial, yaitu ibadah yang manfaatnya menitik-beratkan pada kepentingan orang banyak (umum). Kedudukan ibadah yang terakhir inilah yang memiliki keistimewaan tersendiri dalam ajaran agama Islam (Wahab, 2015: 1). Disebutkan dalam kaidah fiqih "ibadah yang bermanfaat kepada orang lain lebih utama dari pada ibadah yang manfaatnya hanya kepada diri sendiri."

Franz Magnis Suseno (Suseno, 2015: 8) mengatakan “orang beragama tidak dapat dikatakan beragama dengan sungguhsungguh jika dia tidak konsekuen menghormati martabat saban orang sebagai manusia. Tanpa membedakan jenis kelamin, kepercayaan, agama, pandangan politis, suku, ras, kedudukan sosial dan lain sebagainya. Bisa juga dikatakan, bahwa di zaman modern yang cenderung sekularis, klaim agama-agama bahwa mereka menawarkan kebaikan Allah kepada manusia hanya akan kredibel apabila kaum agama sendiri nampak berperi kemanusiaan". Pandangan diatas menunjukkan dalam beragama juga tidak hanya kesalehan spiritual saja yang perlu ditingkatkan, namun juga kesalehan sosial, yaitu hubungan baik antar sesama untuk menciptakan kehidupan yang harmoni.

Pentingnya agama-agama menjadi rabmatan lil alamin di Indonesia. Agama menjadi rahmat bagi bangsa dan segenap semesta, dan semestinya bukan hanya berlaku bagi agama Islam saja (Kolimon, 2015: 34). Namun, bagi semua agama di Indonesia. 
Agama Islam, Katolik, Protestan, Hindu, Budha, dan semua agama suku di negeri ini haruslah menjadi berkah bagi bangsa ini dan segenap ciptaan Allah yang ada di bumi Indonesia.

Kerukunan umat beragama di Indonesia masih ibarat api dalam sekam (Mufid, 2015: 76). Jika kita berkunjung ke daerah-daerah, termasuk daerah konflik, laporan pejabat setempat selalu menyatakan daerahnya kondusif, aman dan damai. Tetapi siapa yang dapat menjamin, kalau daerah tersebut tiba-tiba terjadi konflik antar umat beragama atau internal umat beragama.

Gus Dur pernah menuliskan bahwa kerukunan antar umat beragama di Indonesia masih bersifat permukaan saja (Wahid 2015:66). Asal tidak terjadi gesekan, sudah disebut rukun. Tetapi menurut Gus Dur, kerukunan antar umat beragama sejati adalah ketika kita mampu melihat titik-titik persamaan, dan menggunakannya untuk kepentingan bersama. Kita perlu ingat ungkapan populer yang sering beliau lontarkan "yang sama jangan dibeda-bedakan, yang beda jangan disama-samakan."

Ini menunjukkan lebih jelas, bahwa perbedaan pendapat itu penting, tetapi pertentangan dan keterpecah-belahan adalah sebuah malapetaka (Wahid 2006: 29). Dengan demikian, nampak bahwa perbedaan, yang menjadi inti sikap dan pandangan perorangan harus dibedakan dari pertentangan dan keterpecah-belahan dari sebuah totalitas masyarakat.

Pandangan para ulama yang begitu beragam menunjukkan bahwa yang paling penting adalah kejujuran untuk menerima perbedaan dan keragaman pendapat, dimana kejujuran itu dilandasi sebuah pemahaman yang komprehensif dan argumentative (Misrawi, 2010: 136). Sikap tersebut harus diimplementasikan dalam kehidupan berbangsa dan bernegara sehingga kalangan muslim dapat memberikan kontribusi yang bersifat konstruktif.

Selanjutnya, banyak terjadinya konflik antar suku diberbagai daerah di Republik ini, di Provinsi Lampung misalnya konflik antar suku Lampung dan Bali di Kabupaten Lampung Selatan pada tahun 2012 dan banyak lagi catatan panjang konflik antar suku di Provinsi Lampung yang lainnya. Jika kita melihat, Provinsi Lampung adalah 
daerah yang heterogen, terdiri dari suku asli Lampung dan pendatang.

Oleh karenanya, dalam menyikapi keberagaman baik suku, ras, agama, kepercayaan maka perlunya sikap toleransi agar hidup berdampingan saling menghargai perbedaan satu-sama lain, dan tidak menimbulkan perpecahan untuk dapat bertahan untuk dapat berperan menjaga dan merawat perdamaian dan kerukunan sesama bangsa (Nafi, 2018: 8). Karena itu menjadi faktor penting didalam mengelola negara dan bangsa yang majemuk.

Toleransi memiliki makna dua sisi ( Nurjanah, 2013: 131), di satu sisi, setiap umat Islam harus memiliki keyakinan dan kefanatikan yang kuat terhadap akidahnya. Di sisi lain, umat Islam diharuskan memahami dan menghargai pemeluk agama, dan suku lainnya. Toleransi adalah kemampuan untuk menghormati sifat dasar, keyakinan, dan perilaku yang dimiliki oleh orang lain. Dalam literature agama, toleransi disebut tasamub yang dipahami sebagai sikap saling menghargai, membiarkan, atau membolehkan pendirian atau pandangan orang lain yang bertentangan dengan kita (Shihab, 1998: 41).

Keragaman dan toleransi adalah pasangan kata yang memang tepat dipersandingkan (Syam, 2018: 84). Keragaman merupakan keniscayaan di dalam kehidupan ini, sebab tidak ada masyarakat yang tidak beragam keadaannya. Keragaman dalam etnis, suku, agama, bahasa, dan budaya. Di dalam suatu masyarakat yang paling simple sekalipun pasti terdapat suatu keadaan yang beragam. Keragaman bisa dikaitkan dengan kata pluralitas dan juga multikulturalitas.

Karena sesungguhnya yang paling penting untuk dijunjung adalah kemanusiaan, dengan memahami perbedaan maka kita telah menghargaai dan meninggikan sikap kemanusiaan (Barton, 1999: 407). Bagi Gus Dur, Islam, baik sebagai pandangan dunia maupun pikiran-pikiran dasar, meletakkan kerangka dasar bagi pandangan dunia kemanusiaan yang luar biasa.

Indonesia sebagai sebuah bangsa dan negara didirikan dengan keterlibatan dan kesadaran penuh dari para tokoh bangsa bahwa 
Indonesia adalah bangsa yang majemuk, maknanya dalam ruang kehidupan sehari-hari sejak nenek moyang dahulunya, masyarakat Indonesia sudah terbiasa dengan kehidupan keberagaman secara berdampingan dengan damai.

Perbedaan etnik maupun agama bukan penghalang bagi mendirikan Negara yang berkeadilan, bahkan perbedaan menjadi suatu kekayaan, kekuatan, dan potensi dalam membangun bangsa Indonesia ke depan yang lebih baik. Maknanya kalau dilihat dari sisi historis bangsa Indonesia sejak dulu sudah hidup dalam perbedaan dengan harmoni, namun seiring perkembangan zaman dan dengan berbagai perubahan sosial budaya telah membawa pengaruh kepada hidup harmoni tersebut, lebih parahnya lagi memporak-porandakan harmoni.

Ternyata "merawat" itu lah yang paling sulit dibandingkan membangun. Perubahan adalah sesuatu yang tidak bisa dielakkan, karena perubahan adalah kehidupan itu sendiri. Masyarakat dan kebudayaan akan selalu mengalami perubahan dan dinamika, karena perubahan adalah indikator kemajuan. Oleh karena itu perlu upaya-upaya untuk merawat hidup harmoni dalam dinamika perubahan sosial budaya masyarakat (Nurdin, 2018: 1-4).

Untuk itu, perlunya sikap memahami, menghargai satu sama lain dalam bingkai perbedaan, maka untuk mewariskan sikap arif yang berkenaan dengan penghargaan satu-sama lain jalur yang tepat adalah melalui pendidikan, pendidikan secara sistematis mampu menanamkan nilai-nilai tersebut. Pentingnya pendidikan umat untuk mengasuh spirit keragaman dalam kehidupan bangsa Indonesia, (Kolimon 2015: 33).

\section{Pendidikan Multikultural}

Pentingnya pendidikan sebagai proses transformasi nilai, maka pendidikan pluralis-multikultural sangat penting dengan harapan mewujudkan sebuah kehidupan yang harmoni, damai, selaras, dan berperadaban dengan mengedepankan semangat bekerjasama dan menegakkan kebenaran, kebaikan, menjauhi segala bentuk kerusakan yang mengedepankan kemanusiaan karena sejatinya 
menurut Diyarkara (Driyarkara, 1980: 8) pendidikan merupakan proses memanusiakan manusia dimana manusia diharapkan mampu memahami dirinya, orang lain, alam dan lingkungan budayanya.

Secara bahasa, kata pluralis berasal dari bahasa inggris plural yang berarti jamak, dalam arti keanekaragaman dalam masyarakat, atau ada banyak hal lain di luar kelompok kita yang harus diakui. Secara istilah, pluralism bukan sekedar keadaan atau fakta yang bersifat plural, jamak, atau banyak (Noer, 1999: 872). Lebih dari itu, pluralism secara substansial termanifestasi dalam sikap saling menghargai, menghormati, memelihara, dan bahkan mengembangkan atau memperkaya keadaan yang bersifat plural, jamak, atau banyak.

Adapun multikulturalisme akar katanya adalah kebudayaan, multikulturalisme secara etimologis dibentuk dari kata multi (banyak), kultur (budaya), dan isme (aliran atau paham) (Mahfud, 2016: 75). Pada hakikatnya, dalam kata tersebut terkandung pengakuan akan martabat manusia yang hidup di dalam komunitasnya dengan kebudayaannya masing-masing yang unik.

Multikulturalisme menurut Suparlan sebagai sebuah ideologi, multikulturalisme terserap dalam berbagai interaksi yang ada dalam berbagai struktur kegiatan kehidupan manusia (Suparlan, 2002: 100). Dengan demikian, walaupun ada beberapa yang memahami secara berbeda antara pengertian dari pluralisme dan multikulturalisme, perbedaanya tidak signifikan, secara umum bahkan memiliki banyak kesamaan (Syahputra, 2018: 36-38).

Sebagaimana disebutkan diatas, perlunya pendidikan multikultural dalam menanamkan nilai pemahaman akan keberagaman, sebelum terlalu jauh, perlunya mengetahui definisi pendidikan multikultural. Secara sederhana pendidikan multikultural, dapat didefinisikan sebagai "pendidikan untuk/tentang keragaman kebudayaan dalam merespon perubahan demografis dan kultural lingkungan masyarakat tertentu atau bahkan dunia secara keseluruhan" (Ibrahim, 2013: 139).

Dalam hal pendidikan multikultural, sekolah harus mendesain proses pembelajaran, mempersiapkan kurikulum dan desain 
evaluasi, serta mempersiapkan guru yang memiliki persepsi, sikap, dan perilaku multikultur, sehingga menjadi bagian yang memberikan kontribusi positif terhadap pembinaan sikap multikultur para siswanya (Rosyada, 2014: 12). Termasuk dalam menyesuaikan pendidikan multikultural yang cocok untuk tiap-tiap daerah, disini penulis menawarkan konsep pendidikan multikultural yang terkandung dalam kearifan lokal.

Kearifan lokal atau local wisdom merupakan representasi dan ekspresi pengalaman panjang dalam mengelola dan mengatasi berbagai persoalan hidup yang dijalani setiap hari ataupun hariharinya yang panjang yang meliputi segala aspek kehidupan dari pendidikan, ekonomi, sosial, politik, kesehatan hingga ketuhanan, mereka belajar bukan dari teks tetapi dari alam, diri sendiri dan sesama.

Hasilnya kemudian diwariskan (transmisi) ke generasi baru sebagai tradisi yang mereka pegang kukuh secara turun-temurun, tetapi mereka meyakini kebenarannya dan sudah sejak lama menjadi pemandu hidupnya (Mulkhan, 2007: 137-45). Kita menilai nilai-nilai itu sebagai kearifan lokal, karena itu menjadi penting bagi lembaga pendidikan tinggi merekonstruksi kearifan lokal yang kaya di negeri ini (Mulkhan, 2013: 63).

Masyarakat termasuk lingkungan pendidikan, selain dalam keluarga dan lembaga sekolah, sejatinya proses pendidikan juga terjadi di lingkungan masyarakat melalui penanaman nilai-nilai luhur yang disebut oleh sebagai pengetahuan lokal atau local knowledge atau yang kini kita pahami dengan kearifan lokal (Geertz, 1983: 167-71).

Pendidikan di Indonesia selama ini terlihat cenderung menyeragamkan, sehingga sulit di implementasikan di tiap-tiap daerah yang seharusnya disesuaikan dengan budaya sekitar, sebagaimana menurut Farida Hanum bahwa budaya dalam kehidupan masyarakat sangat penting karena menjadi alat perekat di dalam suatu komunitas (Hanum, 2012: 2). Sebenarnya, pendidikan pluralis-multikultural dalam adat-istiadat di Indonesia telah ada, 
seperti halnya konsep pendidikan multikultural dalam budaya Lampung yang akan menjadi topik bahasan artikel ini.

\section{Gambaran Umum Provinsi Lampung}

Masyarakat di Provinsi Lampung adalah masyarakat yang majemuk atau multietnis dan berbagai kepercayaan agama yang dianut, bahkan dalam pandangan Chairul Anwar (2019), Provinsi Lampung disebut Indonesia mini yang terdiri dari berbagai macam suku seperti Lampung, Jawa, Bali, Ogan, Batak, Bugis, Semendo, Daya, Palembang, Sunda dan lain sebagainya.

Marsden dalam bukunya (2016) mengatakan wilayah Lampung diketahui sebagai bagian wilayah yang terletak dari ujung paling selatan pulau Sumatera, merupakan pintu gerbang lalu lintas melalui jalur darat pulau Jawa melalui pelabuhan Merak ke pelabuhan Bakauheni. Secara geografis wilayah Provinsi Lampung memiliki luas $35.376 \mathrm{~km} 2$ atau setara dengan $3.528 .835 \mathrm{ha}$, adapun ibukota Provinsi Lampung adalah Kota Bandar Lampung.

Berdasarkan garis peta-bumi letak Provinsi Lampung antara $130^{\circ} 40^{1}-150^{\circ} 50^{1}$ bujur timur dan $6^{\circ} 45^{1}-3^{\circ} 45^{1}$ lintang selatan adapun batas-batas wilayah Provinsi Lampung yaitu dari sebelah utara berbatasan dengan Provinsi Sumatera Selatan dan Provinsi Bengkulu, dari sebelah selatan berbatasan dengan selat Sunda, dari sebelah barat berbatasan dengan samudera Hindia, dan dari sebelah timur berbatasan dengan laut Jawa (SA, 2012: 35).

Adapun pada tulisan diawal, penulis banyak menyinggung tentang ke-Islaman, hal ini dikarenakan budaya Lampung dan Islam adalah dua hal yang tidak dapat dipisahkan seperti diungkapkan A. Fauzie Nurdin "Islam dan budaya Lampung telah terjadi percampuran, pengkombinasian, dan perpaduan paham yang saling mengisi dan bersinergi (Nurdin, 2010: 69), hal ini merupakan proses sejarah panjang akulturasi Islam dan budaya di Lampung (Syahputra, 2017: 9-20), menurut Syaripudin Basyar "ketika kita berbicara soal Lampung maka Lampung itu adalah Islam, tidak pernah kita jumpai pribumi Lampung yang tidak beragama Islam” (Basyar, 2014: 89). 
Masyarakat adat Lampung memiliki pandangan hidup yang disebut falsafah hidup ulun Lappung (arti: orang Lampung) atau falsafah piil pesenggiri yang didalamnya terdapat lima unsur piil pesenggiri itu sendiri yang bermakna harga diri, juluk adek; berperilaku sesuai gelar adat, nemui nyimah; ramah dalam menerima tamu, nengah nyappur; pandai bergaul, sakai sambaiyan; gotong-royong (Syahputra, 2020: 1-10).

\section{Pengertian Nemui Nyimah}

Sebagai kearifan lokal Lampung, pandangan hidup orang Lampung atau falsafah hidup ulun Lappung diatas, menurut penulis terdapat salah satu unsur yang memiliki nilai multikultural yaitu unsur nemui nyimah. Secara bahasa menurut Chairul Anwar (2019) Nemui berasal dari kata benda temui yang berarti tamu, kemudian menjadi kata kerja nemui yang berarti mertamu atau silaturahmi/mengunjungi.

Sedangkan, nyimah berasal dari kata benda simah, yang kemudian menjadi kata kerja nyimah yang berarti suka memberi atau pemurah. Secara harfiah nemui nyimah diartikan sebagai sikap pemurah, santun, suka memberi, terbuka tangan dan menerima dalam arti sesuai kemampuannya. Nemui nyimah merupakan ungkapan asas kekeluargaan yang menciptakan sikap kerukunan dan keakraban serta silaturahmi. Unsur inilah yang akan penulis kaji secara mendalam dalam artikel ini tentang bagaimana "Pendidikan Multikultural dalam budaya Nemui Nyimab"

\section{Metode Penelitian}

Pendekatan yang digunakan dalam penelitian ini adalah pendekatan kualitatif (Dyah, 2005: 25). Alasan menggunakan penelitian kualitatif dikarenakan, penelitian ini dilakukan untuk memperoleh gambaran secara mendalam mengenai objek penelitian yaitu bagaimana "Pendidikan Multikultural dalam budaya Nemui Nyimab". Oleh karena itu penulis dalam penelitian ini memilih pendekatan kualitatif. 
Metode penelitian dalam penelitian dilakukan dengan cara deskriptif-kualitatif dengan menggunakan kajian pustaka (library research). Penelitian ini merupakan penelitian kepustakaan, mencari dan menyitir dari bermacam-macam sumber data yang berkaitan dengan permasalahan yang diteliti berupa dokumen kepustakaan (Sukardi 2015: 34). Kajian pustaka adalah proses kegiataan menelaah bahan-bahan pustaka tersebut (Sanjaya, 2015: 205), tanpa melalui penelitian yang dilakukan di lapangan,

Penulis dalam penelitian ini menekankan pada kekuatan analisis sumber-sumber dan data-data yang ada dengan mengandalkan teori-teori dan konsep-konsep untuk kemudian di interpretasikan berdasarkan tulisan-tulisan yang relevan pada pembahasan.

\section{Hasil Penelitian dan Pembahasan}

Masyarakat sebagai lingkungan pendidikan sudah barang tentu menjadi tempat terbentuknya pemikiran, perasaan atau sikap, dan perbuatan. Hal ini menunjukkan lingkungan sekitar sangat berpengaruh dalam proses pendidikan seorang anak, maka dapat dikatakan seseorang terbentuk pengetahuannya, sikapnya, dan perilakunya tidak lepas dari peran lingkungan masyarakat. Telah penulis sebutkan diatas bahwa orang Lampung memiliki falsafah hidup yang disebut sebagai piil pesenggiri, jika suatu masyarakat atau etnik memiliki pandangan hidup, maka segala bentuk kegiatan kebudayaan dan adat istiadat tidak terlepas dari pandangan hidup tersebut, secara singkat pola pikir, sikap, perilaku orang Lampung tercermin dari falsafah hidup ulun Lappung.

Kearifan lokal sudah pasti didalamnya terkandung nilai-nilai luhur yang arif sebagaimana keluhuran yang terkandung dalam unsur-unsur falsafah hidup ulun Lappung. Namun demikian, mengapa di Lampung masih saja terjadi konflik antar suku, hal ini disebabkan kurangnya masyarakat etnik Lampung dalam memahami falsafah hidupnya, atau justru pemahaman yang salah akan falsafah hidup tersebut, falsafah piil pesenggiri yang berarti harga diri justru terkadang digunakan untuk membela harga diri dengan arogansi. Dengan demikian, penulis merasa perlu untuk 
menganalisa nilai luhur yang terkandung dalam nemui nyimah sebagai salah satu unsur dalam falsafah hidup ulun Lappung.

\section{Pendidikan Multikultural dalam Budaya Nemui Nyimah}

Nemui nyimah sebagai konsep budaya lokal yakni berbagi dengan tamu, ramah kepada tamu, sopan santun, pemurah dengan tamu yang merupakan harga diri atau piil pesenggiri bagi mereka jika dalam menerima tamu tidak dilayani dengan baik (Nurdin, 2017: 84). Nemui nyimah tidak hanya sebagai unsur dalam falsafah hidup ulun Lappung saja, namun telah menjadi budaya bagi orang Lampung dalam kehidupan sehari-harinya dalam memperlakukan tamu dan juga menyikapi perbedaan dalam kehidupan masyarakat yang majemuk di Provinsi Lampung.

Berbagi dengan tamu, di Lampung mereka biasa menjamu orang-orang asing dengan jauh lebih mewah dibandingkan dengan cara masyarakat Sumatera di daerah lainnya. Jika tamu tersebut termasuk orang penting, mereka tanpa ragu-ragu mereka akan menyembelih unggas, kambing, seekor atau beberapa ekor kerbau sesuai dengan lama tinggal dan jumlah tamu yang menginap (Marsden, 2016: 443).

Berdasarkan catatan Marsden tersebut, orang Lampung dalam melayani tamu sangat luar biasa saat memberikan jamuan berupa hidangan, walaupun tamu dari luar daerah. Hingga sekarang jika kita bertamu di rumah orang Lampung maka, apapun makanan yang dimilikinya akan dikeluargan untuk tamu yang datang. Sikap dan perilaku inilah menunjukkan bahwa orang Lampung ini tidak perhitungan, melayani, menerima tamu dari berbagai latar belakang suku, maupun agama yang hadir sebagai wujud dari sikap multikultural.

Ramah kepada tamu, Jika kita lihat sejarah masyarakat Lampung yang ketika itu kedatangan para pendatang dari Pulau Jawa transmigrasi masa kolonialisasi (Nurdin, 2017: 84). Keluarga migran yang direkrut dari Jawa mencapai Batavia (sekarang Jakarta) dengan kereta api, kemudian menuju ke Lampung dengan kapal api 
(Levang, 2003: 131), maka sesungguhnya perbedaan bagi masyarakat Lampung sudah tidak asing lagi.

Orang Lampung dalam sejarahnya sangat menerima dan ramah kepada tamu, tamu disini bukan yang dimaksud sebagai tamu yang datang kemudian pergi saja, namun tamu yang datang untuk tinggal dan menetap di Provinsi Lampung. Terbukti di Lampung terdapat berbagai suku pendatang seperti Jawa, Sunda, Batak, Padang, Palembang, Semendo, Ogan, Daya, Bugis, Aceh dan lain sebagainya, hal ini membuktikan bahwa masyarakat di Lampung terbiasa dengan perbedaan-perbedaan, yang menunjukkan sikap dan perilaku menerima terhadap perbedaan dalam kehidupan sosial masyarakat, hal ini salah satu bagian dari multikulturalisme yang menjunjung toleransi ditengah perbedaan.

Sopan santun dan pemurah dengan tamu, sebagai tuan rumah, Orang Lampung tidak serta merta memandang dirinya sebagai etnik yang menguasai suatu wilayah sehingga akan menimbulkan kecongkakan, orang Lampung dalam sikap dan berperilaku dengan tamu atau suku lain dirinya akan menjunjung tinggi sopan santun, hal ini dikarenakan piil pesenggiri atau harga diri, orang Lampung akan malu apabila dirinya dalam berperilaku dan bersikap tidak menjunjung sopan santun dan pemurah dengan tamu, dan karena malu dapat menjatuhkan harga dirinya, maka bersikap baik kepada tamu, pendatang, dan suku lain merupakan suatu keharusan bagi orang Lampung, hal ini menunjukkan ciri-ciri etnik yang menjunjung tinggi perbedaan lintas etnik, sikap dan perilaku sopan santun, pemurah akan menimbulkan saling hormat satu sama lain yang mengesampingkan perbedaan-perbedaan, dan lebih mementingkan kesamaan-kesamaan yang ada satu sama lain.

Dari nilai-nilai multikultural diatas, harapannya tidak hanya menjadi khazanah yang dapat membentuk pemikiran, sikap, dan perilaku anak dalam kehidupan masyarakat saja, namun juga dapat dikembangkan satu persatu didalam lingkungan pendidikan formal baik sekolah, madrasah, maupun perguruan tinggi di Provinsi Lampung. 


\section{Catatan Akhir}

Masyarakat Lampung merupakan masyarakat yang heterogen, terdiri dari berbagai macam suku dan kepercayaan yang mereka anut, hal ini satu sisi adalah kekayaan, namun dididi lain dapat menimbulkan konflik. Oleh sebab itu perlunya mengedepankan pendidikan pluralis-multikultural sebagai bentuk transfer nilai pemahaman akan penerimaan terhadap perbedaan yang dapat menciptakan kehidupan yang harmoni di tengah perbedaan. Dalam menentukan format pendidikan multikultural, perlunya diambil dari kearifan lokal etnik setempat, karena format dari luar seringkali tidak cocok dengan suatu daerah. Kebudayaan dan kehidupan sehari-hari etnik Lampung tercermin dalam falsafah hidupnya yang sering disebut sebagai falsafah hidup ulun Lappung atau falsafah piil pesenggiri. Adapun lima unsur didalam piil pesenggiri, salah satu unsurnya bernilai multikultural adalah unsur nemui nyimah, nemui nyimah yang bermakna berbagi dengan tamu, ramah kepada tamu, sopan santun, pemurah dengan tamu, nilai-nilai ini yang lemudian dapat dikembangkan dalam lembaga pendidikan dan madrasah.

\section{Daftar Pustaka}

Barton, Greg. 1999. Gagasan Islam Liberal di Indonesia: Pemikiran NeoModernisme Nurcholish Madjid, Djohan Effendi, Abmad Wabib, dan Abdurrabman Wabid. Jakarta: Paramadina.

Basyar, Syaripudin. 2014. Determinasi Nilai-nilai Tradisi Terhadap Religiusitas Masyarakat Kajian Adat Ninjuk dalam Budaya Lampung. Bandar Lampung: LP2M IAIN Raden Intan Lampung.

Driyarkara. 1980. Tentang Pendidikan. Jakarta: Kanisius.

Dyah, H. M. 2005. Penelitian Kualitatif Dalam Penerapan. Pekanbaru: Depdiknas Pusat Bahasa.

Geertz, Clifford. 1983. Local Knowledge: Further Essays in Interpretive Anthropology. USA: Basic Books Inc.

Hamdi, Ahmad Zainul, dan Muktafi, ed. 2017. Politik Pluralisme dan Multikulturalisme di Indonesia: Wacana dan Praktik Pluralisme Keagamaan di Indonesia. Jakarta Selatan: Daulat Press. 
Hanum, Farida. 2012. Pendidikan Multikultural dalam Pluralisme Bangsa. Yogyakarta: Lemlit UNY.

Ibrahim, Rustam. 2013. Pendidikan Multikultural: Pengertian,

Prinsip, dan Relevansinya dengan Tujuan Pendidikan Islam. ADDIN: Media Dialektika Ilmu Islam. 7 (1).

Kolimon, Mery. 2015. Agama Menjunjung Kemanusiaan: Agama,

Keterbukaan dan Demokasi: Harapan dan Tantangan. Jakarta

Selatan: Pusat Studi Agama dan Demokrasi Yayasan Paramadina.

Levang, Patrice. 2003. Ayo ke Tanah Sabrang: Transmigrasi di Indonesia. Jakarta: Kepustakaan Populer Gramedia.

Mahfud, Choirul. 2016. Pendidikan Multikultural. Yogyakarta: Pustaka Pelajar.

Marsden, William. 2016. Sejarah Sumatera: The History of Sumatera. Yogyakarta: Penerbit Indoliterasi.

Misrawi, Zuhairi. 2010. Hadratussyaikh Hasyim Asy'ari: Moderasi, Keumatan, dan Kebangsaan. Jakarta: Kompas Media Nusantara. Mufid, Ahmad Syafi'i. 2015. Kebebasan Beragama dan Kesejabteraan Bangsa (Kerukunan dan Kedamaian adalah Keniscayaan: Agama, Keterbukaan dan Demokasi: Harapan dan Tantangan). Jakarta Selatan: Pusat Studi Agama dan Demokrasi Yayasan Paramadina.

Mulkhan, Abdul Munir. 2007. Pembelajaran Filsafat Berbasis Kearifan Lokal. Jurnal Filsafat. 17 (2).

Mulkhan, Abdul Munir. 2013. Kearifan Lokal dalam Tradisi dan Serat: Sumber Rekonstruksi Karakter Religius Bangsa. IJC: Indonesian Journal of Conservation. 2 (1).

Nafi, M. Zidni. 2018. Menjadi Islam, Menjadi Indonesia. Jakarta: Elex Media Komputindo.

Naim, Ngainun. 2015. Pengembangan Pendidikan Aswaja Srbagai Strategi Deradikalisasi. Walisongo: Jumal Penelitian Sosial Keagamaan. 23 (1).

Naim, Ngainun. 2016. Membangun Kerukunan Masyarakat Multikultural. HARMONI: Jurnal Multikultural \& Multireligius. 15 (1). 
Noer, Kauzhar Azhari. 1999. Menyemarakekan Dialog Agama: Dekonstruksi Islam Madz̧ab Ciputat. Bandung: Zaman Wacana Mulia.

Nurdin, A. Fauzie. 2010. Integralisme Islam dan Budaya Lokal: Relevansi Nilai-Nilai Filosofis Kebudayaan Bagi Pembangunan Daerah. Yogyakarta: Gama Media.

Nurdin, Bartoven Vivit. 2017. Nemui Nyimah: Kearifan Lokal untuk Pembangunan Toleransi yang Berkualitas: Bunga Rampai: Pemikiran Anggota Dewan Riset Daerah (DRD) Provinsi Lampung. Bandar Lampung: AURA Publishing.

Nurdin, Bartoven Vivit. 2018. Merawat Hidup Harmoni Dalam Keberagaman. Lampung Post. Februari (15).

Rosyada, Dede. 2014. Pendidikan Multikultural di Indonesia

Sebuah Pandangan Konsepsional. Jurnal Sosio Didaktika. 1 (1).

SA, Sabaruddin. 2012. Lampung Pepadun dan Saibatin. Jakarta: Buletin Way Lima Manjau.

Sanjaya, Wina. 2015. Penelitian Pendidikan: Jenis, Metode dan Prosedur. Jakarta: Prenada Media Group.

Shihab, Alwi. 1998. Islam Inklusif, Menuju Sikap Terbuka dalam Beragama. Bandung: Mizan.

Sukardi. 2015. Metodologi Penelitian Pendidikan: Kompetensi dan Praktiknya. Jakarta: Bumi Aksara.

Sumbulah, Umi, dan Nurjanah. 2013. Pluralisme Agama: Makna dan Lokalitas Pola Kerukunan Antarumat Beragama. Malang: UIN Maliki Press.

Suparlan, Parsudi. 2002. Menuju Masyarakat Indonesia yang

Multikultural. Makalah. Universitas Udayana, Denpasar.

Suseno, Franz Magnis. 2015. Agama, Kebangsaan dan Demokrasi:

Nurcholish Madjid dan Kemanusiaan: Agama, Keterbukaan dan Demokasi: Harapan dan Tantangan. Jakarta Selatan: Pusat Studi Agama dan Demokrasi Yayasan Paramadina.

Syahputra, Muhammad Candra. 2017. Napaktilas Jejak Islam Lampung. Yogyakarta: Global Press.

Syahputra, Muhammad Candra. 2018. Pendidikan Islam Multikultural (Studi Komparasi Pemikiran Abdurrahman 
Wahid dan Nurcholish Madjid). Skripsi. UIN Raden Intan Lampung, Lampung.

Syahputra, Muhammad Candra. 2020. Nilai-Nilai Pendidikan Karakter dalam Budaya Nengah Nyappur. Jurnal PAI Raden Fatah. 2 (1).

Syam, Nur. 2018. Menjaga Harmoni Menuai Damai: Islam, Pendidikan, dan Kebangsaan. Jakarta Timur: Kencana.

Wahab, Abdul Jamil, ed. 2015. Indeks Kesalehan Sosial Masyarakat Indonesia. Jakarta: Badan Litbang dan Diklat Pulsitbang Kehidupan Keagamaan Kementrian Agama RI.

Wahid, Abdurrahman. 2006. Islamku Islam Anda Islam Kita: Agama Masyarakat Negara Demokerasi. Jakarta: The Wahid Institute.

Wahid, Alissa. 2015. Agama dan Hirarki Nilai dalam Praktik Kebangsaan Indonesia. dalam Agama, Keterbukaan dan Demokasi: Harapan dan Tantangan. Jakarta Selatan: Pusat Studi Agama dan Demokrasi Yayasan Paramadina.

Yaqin, Muhammad Ainul. 2005. Pendidikan Multikultural: CrossCultural Understanding Untuk Demokrasi dan Keadilan. Yogyakarta: Pilar Media. 